\title{
Evaluation of pharmaceutical assistance in municipalities in the state of Minas Gerais
}

\author{
Cristiano Soares de Moura*1, Edson Perini² \\ ${ }^{1}$ Multidisciplinary Institute of Health, Federal University of Bahia, ${ }^{2}$ Center of Drug Studies, Faculty of Pharmacy, Federal \\ University of Minas Gerais
}

\begin{abstract}
The study proposal was to evaluate the pharmaceutical assistance in the state of Minas Gerais (MG) utilizing pharmaceutical assistance indicators described in the literature. The evaluated items were: organization, financing, selection, acquisition, programming, distribution, availability and storage of medicines in 18 municipalities of the Regional Management of Health of Belo Horizonte. The results have shown good performance respecting service organization, presence and updating of Municipal Essential Drug List. The main problems were related to stock control and availability of some items. The work has demonstrated the operational viability of indicators, as to evaluate the conditions of pharmaceutical assistance, as to monitor their performance.
\end{abstract}

Uniterms: Pharmaceutical assistance. Health services/evaluation.

\begin{abstract}
A proposta do estudo foi avaliar a assistência farmacêutica no estado de Minas Gerais (MG), utilizando indicadores da assistência farmacêutica descritos na literatura. Os itens avaliados foram: organização, financiamento, seleção, aquisição, programação, distribuição, disponibilidade e armazenamento de medicamentos em 18 municípios da Gerência Regional de Saúde de Belo Horizonte. Os resultados mostraram bom desempenho quanto à organização do serviço, presença e atualização da Relação Municipal de Medicamentos. Os principais problemas foram em relação ao controle de estoque e disponibilidade de alguns itens. O trabalho demonstrou a viabilidade operacional dos indicadores, tanto para avaliar as condições dos serviços farmacêuticos, quanto para monitorar seu desempenho.
\end{abstract}

Unitermos: Assistência farmacêutica. Serviços de saúde/avaliação.

\section{INTRODUCTION}

The institutionalization of the Unified Health System (Sistema Único de Saúde - SUS) has drastically changed the model of Brazilian health system. From the organizational point of view, the main change was the decentralization of services with a single direction in every government sphere and emphasis in the municipalization of actions. As a matter of fact, along the process, the responsibilities, attributions and resources in health have passed to be more and more shared by the state and municipal spheres. This logic considers the municipality as the more adequate governmental entity to treat the health issue, because it is closer to population (Barata et al., 2004). The health

\footnotetext{
*Correspondence: C. S. Moura. Instituto Multidisciplinar de Saúde, Universidade Federal da Bahia. Av. Olívia Flores, 3.000 - Candeias - 45.055-090 -Vitória da Conquista-BA, Brazil.E-mail: csmoura@ufba.br, eperini@ufmg.br
}

services under responsibility of local administrations were amplified and diversified, among them the pharmaceutical assistance (PA), which is defined in the National Medicines Policy (Política Nacional de Medicamentos - PNM) as a "group of activities related with medications, destined to support the health actions demanded by a community" (Brasil, 1998).

The theoretical construction of PA and its organization proposals seek the expansion of access and the promotion of rational use of medicines. Its arrangement is grounded in the basic principles of SUS, mainly in the strategy of management decentralization. The first effective step was the institution, in 1999, of the Incentive to Basic Pharmaceutical Assistance (Incentivo à Assistência Farmacêutica Básica - IAFB) (Brasil, 1998), establishing the mutual financial responsibility between the three levels of government, which has promoted a progressive autonomy to states and municipalities for the management of financial 
resources. The criteria for qualification to IAFB have included the elaboration of a State Plan of Basic Pharmaceutical Assistance (Plano Estadual de Assistência Farmacêutica Básica), which should make explicit the list of essential drugs as well as the systematic for programming, followingup, controlling, and evaluation of its implementation. In view of this reorientation, the State Secretariat of Health of Minas Gerais (Secretaria de Estado de Saúde de Minas Gerais - SES/MG), by means of the Coordination of Basic Pharmaceutical Service (Coordenadoria de Assistência Farmacêutica Básica - CAF), has installed in 2003 the Programa Farmácia de Minas (PFM). Complementary to other state initiative, the PFM has as one of its fundamental axis the "subsidy to municipalities for the organization and implementation of pharmaceutical assistance" in order to promote their "amplification of managerial capacity" (Superintendência, 2003, 2004).

The importance of PA for the healthcare, its consolidation and improvement in the municipalities imposes the necessity of strategies to follow-up the performance of this activity. So, the objective of this study was to evaluate the pharmaceutical assistance in municipalities in the state of Minas Gerais (MG).

\section{MATERIAL AND METHODS}

A transversal study based on the application of a roll of indicators destined to evaluate the pharmaceutical assistance was conducted. The indicators utilized were based on those presented by the World Health Organization - WHO (WHO, 1999, 2003). The study of Cosendey (2000) and the indicators of Management Sciences for Health - MSH (MSH, 1995) were also utilized. The indicators proposed by Cosendey were particularly important, because they reflect better the national reality. The data were collected in structured questionnaires and interview, along with consultation to administrative databases.

The study was developed in the current Regional Health Administration (Gerência Regional de SaúdeGRS) of Belo Horizonte, constituted by 39 municipalities distributed as follows: 26 (67\%) small municipalities (up to 50 thousand inhabitants); nine (23\%) medium sized municipalities (from 50 to 300 thousand inhabitants) and four (10\%) large municipalities (above 300 thousand inhabitants). The choice of this GRS was done by convenience, taking into account the cost and technical-operational aspects. The choice also took into account the fact that the region has a great proportion of state population, has both large and small cities (with a great variety in their organi- zational complexity), besides its political and economic relevance, which together gives the region representativeness in terms of population and as a diffuser source of new trends in healthcare.

The number of municipalities has targeted a sample close to $50 \%$ of the total number of municipalities, privileging in proportional terms the two population ranges with lower number of inhabitants, because of their higher population representativeness. The selection of municipalities took place at random, in every of the three specified ranges. The interviews for data collection were developed with the pharmacists who were responsible for the PA coordination in the municipalities. Data were collected in the local distribution center (a municipal health facility where drugs are stored) and in two health drug dispensing facilities (Unidades de Saude-US). In one of the selected municipalities, there was only one US. So, the sample was constituted by 18 distribution centers and 35 US.

The PA coordinators of the municipalities were contacted to schedule the interviews. During the initial contact, done by phone, it was detailed the research purpose and formalized the invitation for participation.

In the municipalities, the data were collected from three sources: interviews with PA coordinators, in loco observation, and records consultation in the units. In order to characterize the organizational structure of PA, interviews were developed with the people responsible for such activity in the municipality. The municipalities presenting pharmaceutical assistance in the organization chart of the Municipal Secretariat of Health, and having also a Municipal Plan of Pharmaceutical Assistance, were considered as presenting an organized PA sector. The financing data were collected in the System of Information about Public Budgets in Health (Sistema de Informações sobre Orçamentos Públicos em Saúde - SIOPS), which was made available by DATASUS*. A copy of the Municipal Essential Drugs List (Relação Municipal de Medicamentos - REMUME) was evaluated. If the list (or its update) was more recent than three years, the municipality was classified as having an updated REMUME. Data about drug acquisition were obtained directly from the interviewed people, by requesting them to the purchases department in the municipalities, and by means of consultation to SIOPS. For evaluation of the inventory control, the actual stock in the distribution center, collected by local count, was confronted with the stock registered in the control system (computerized or paper-based).

Actual physical stocks of 20 key drugs were counted. The key drugs list was selected from the State Essential

\footnotetext{
*http://w3.datasus.gov.br/datasus/datasus.php
} 
Drug List: acetylsalicylic acid $100 \mathrm{mg}$ tablet; amoxicillin $500 \mathrm{mg}$ tablet; amoxicillin $50 \mathrm{mg} / \mathrm{ml}$ powder for suspension; benzathine benzylpenicillin $1.200 .000 \mathrm{UI}$; cimetidine $200 \mathrm{mg}$ tablet; diazepam $10 \mathrm{mg}$ tablet; erythromycin $250 \mathrm{mg}$ tablet; erythromycin $25 \mathrm{mg} / \mathrm{mL}$ suspension; glibenclamide $5 \mathrm{mg}$ tablet; hydrochlorothiazide $50 \mathrm{mg}$ tablet; imipramine $25 \mathrm{mg}$ coated tablet; mebendazole $20 \mathrm{mg} / \mathrm{mL}$ tablet; metronidazole $250 \mathrm{mg}$ tablet; paracetamol $500 \mathrm{mg}$ tablet; propranolol $40 \mathrm{mg}$ tablet; oral rehydration salts powder envelope; salbutamol $0,4 \mathrm{mg} / \mathrm{mL}$ oral solution; sulphamethoxazole + trimethoprim $400+80 \mathrm{mg}$ tablet; sulphamethoxazole + trimethoprim $4 \%+0,8$ suspension; ferrous sulphate $25 \mathrm{mg} \mathrm{Fe} / \mathrm{mL}$ oral solution. This list was defined as a parameter for the evaluation of inventory accuracy and availability of essential drugs, based on the presupposition that such drugs should be continuously available in the US. The count values were compared to those recorded in the paper-based or computerized inventory control system. The records presenting a variation of more or less than $5 \%$ respecting to physical count were considered as accordant. The obtained result was categorized as follows: up to $50 \%$ of accordant items - classified as bad; from $50 \%$ to $75 \%$ - classified as reasonable; and above $75 \%$ of accordant items - classified as good.

Programming and distribution components of pharmaceutical assistance chain were analyzed conjunctively, by means of the immediate availability of drugs being verified in the visited local distribution center and US. This information reflects the programming effectiveness in the municipality, by means of the availability of the key drugs in the distribution center and US. Yet respecting to distribution, it was investigated the proportion of key drugs appearing in the municipal distribution center stock and available in the US. Such information could point out the efficiency of the distribution strategy adopted in the municipalities, as it is expected that, with a minimal variation, the drug present in the distribution center, must be present also in the US.

Complementary data respecting the health situation in the municipalities were obtained from secondary databases made available by the Ministry of Health.

Data collected were placed in a Microsoft Access ${ }^{\circledR}$ database. The analysis, expressed in terms of tables of simple frequency distribution and graphics, was done in Microsoft Excel ${ }^{\mathbb{R}}$.

\section{ETHICAL CONSIDERATIONS}

The project has neither an intervention over human subjects, nor used personal information. Even though people were responsible for providing information, they were sought as professionals who were responsible for specific sectors, and all questionings were limited to institutional information. So, it was understood that there were no reason for analysis by an ethics committee, but only for the discretion from the competent instance of SUS, in order to authorize the research. After this authorization, all interviewed people received a presentation letter and an invitation for volunteer participation. They were informed about the study objectives, and the collection instruments were applied only in establishments where the PA responsible had previously verbally consented. It was explained that data would be presented aggregately, without any identification of the interviewed person, municipality, or establishment.

\section{RESULTS AND DISCUSSION}

The visits were done between November, $25^{\text {th }}$ and December, $28^{\text {th }}$ of 2005 . All sampled municipalities were visited. Demographic and health financing data from these municipalities are presented at Table I. One of the 18 distribution centers could not be visited, because of a coincidence between the date scheduled for visit and the local inventory period. In two of the 35 selected US, the person responsible for information was not found. The main difficulties related to information availability occurred with data about drug acquisition, and this item presented the lower index of response within the indicators group, with $39 \%$. Notwithstanding the field operational difficulties, and the low index of responses in the item of drug acquisition, the selected indicators and the data collection process related to them have shown viability, and the grade of responses to the research was satisfactory.

Table II resumes the main results, showing the average, the lower and the higher value found for every of the indicators. The data of this table, in the sub-items A (financing); B (sector organization); C (drug selection); $\mathrm{D}$ (drug acquisition) are referred to information collected in the Municipal Secretariats of Health; therefore, they have summed as a maximum 18 , when the information was available in all the municipalities. The same table data of sub-item E (storage) are referred to information collected in the distribution center and have summed, as a maximum, 17, as it was not possible to detect the data from one distribution center. Only the data reported at sub-item $\mathrm{F}$ (programming/distribution) are referred to simultaneous information in the distribution center (F.1) and the US, completing, therefore, a total of 17 and 33, respectively. For the categorical indicators, the data are presented as the most frequently found percentage of response.

PA appears formally organized in $44 \%$ of the municipalities. No attempt was made to evaluate the quality of 
TABLE I - General characteristics of municipalities. Regional Management of Health of Belo Horizonte, MG, 2005.

\begin{tabular}{lccccc}
\hline & & & \multicolumn{3}{c}{ Characteristics } \\
\cline { 5 - 6 } Indicator & Source & Year & $\begin{array}{c}\text { Municipalities } \\
\text { sampled }\end{array}$ & MG & Brazil \\
\hline Number of cities & IBGE & 2006 & 36 & 853 & $5,560^{1}$ \\
Proportion of cities in the study & - & - & - & $4.2 \%$ & $0.6 \%$ \\
Population (estimation) & IBGE & 2005 & $4,195,463$ & $19,237,450$ & $184,184,264$ \\
Proportion of population in the study & - & - & - & $22.4 \%$ & $2.3 \%$ \\
Proport. pop. older than 60 years (\%) & IBGE & 2003 & 7.51 & 10.2 & 9.5 \\
IDH-M & PNUD & 2000 & $0.767^{2}$ & 0.773 & 0.766 \\
Child mortality (/1.000 born alive) & MS & 2003 & 17 & 20 & 24 \\
Total health expense per inhab. (R\$) & SIOPS & 2004 & 191.64 & 98.69 & 125.5 \\
$\begin{array}{l}\text { Medications expense per inhabitant } \\
\text { (\% of total health expense) }\end{array}$ & SIOPS & 2004 & 4.57 & 7.63 & 6.44 \\
\hline
\end{tabular}

${ }^{1}$ Datum from 2001, according IBGE (http://www.ibge.gov.br/brasil_em_sintese/default.htm - access on Sep/08/2006)

${ }^{2}$ Average of investigated cities

${ }^{3}$ Human Development Index - Municipal

the municipal plans of pharmaceutical assistance, or their respective suitability to local realities; the implementation of these municipal plans was not evaluated, as well. However, this is an important subject to be considered in further evaluations of pharmaceutical assistance. The mean expense with acquisition by means of bidding was of $76 \%$ of resources, and $84 \%$ of the indebted resources were effectively expended. The analysis of mechanisms of stock control showed that in 35\% of local distribution centers, the concordance of physical count was considered as good (Figure 1), while in 53\% of distribution centers this concordance was considered as bad. As an average, $56 \%$ of records corresponded, in quantitative terms, to actual physical stock.

The availability of drug indicators showed that, as

\section{Percentage of actual stock recorded in the control worksheet}
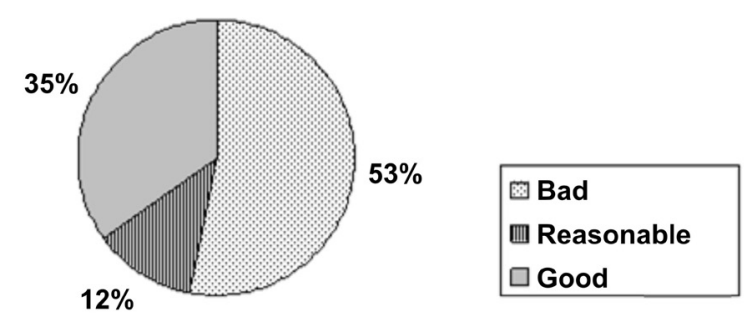

FIGURA 1 - Municipalities distribution as a function of the percentage of physical stock corresponding to records in their stock control instrument. Regional Management of Health of Belo Horizonte, MG, 2005. an average, $89 \%$ of investigated items were present in the distribution centers, while the average availability in the US was of $74 \%$. These results are detailed at Table III, that shows the availability of every of the investigated drugs. Sulphamethoxazole + trimethoprim tablet was the drug that presented the larger availability in the US (88\%), while paracetamol $500 \mathrm{mg}$ presented the lower availability (58\%), together with diazepam $10 \mathrm{mg}$, imipramine $25 \mathrm{mg}$ and the benzathine benzylpenicillin 1.200.00 UI, that were available in only $61 \%$ of the US. Acetylsalicylic acid $100 \mathrm{mg}$, diazepam $10 \mathrm{mg}$ and again sulphamethoxazole + trimethoprim tablets were present in all of the investigated distribution centers. Other drugs with low availability in the distribution centers were the mebendazole suspension (77\%) and the paracetamol $500 \mathrm{mg}$, with $65 \%$. The investigation indicated even that, as an average, $83 \%$ of drugs found in the local distribution center were also available at the US.

The data showed positive results respecting the organization process in pharmaceutical assistance (Marin et al., 2003; Perini, 2003). The majority of municipalities had the REMUME approved and within an acceptable period of updating. Another positive aspect is referred to the drug acquisition mechanism and selection, with a significant percent of municipal expenses done by bidding. The $26 \%$ of expenses done by direct purchase, an acquisition mechanism frequently associated to higher cost, demonstrates the permanence of a practice that progressively looks to be in process of replacement. Even about the acquisition, the data showed efficiency in the execution of municipal 
TABLE II - Evaluated indicators, data sources, objectives, construction strategies and abstract of results obtained for every of investigated indicators respecting management of Pharmaceutical Care. Regional Management of Health of Belo Horizonte, MG, 2005

\begin{tabular}{llllll}
\hline Evaluated indicator & Source & Objective & Construction strategy & \multicolumn{4}{c}{ Results } \\
\cline { 3 - 5 } & & & Mean $\quad$ Lower Higher & $\mathrm{N}$ \\
\hline
\end{tabular}

\section{A. Financing}

A.1. Financial value per capita applied in medications in the city
SIOPS $^{1} \quad$ To evaluate the resources availability in the city for acquisition of basic medications.
Research into public databank (sum of municipal, state, and 12.70 0.46 19.56 18 federal resources)

\section{B. Sector organization}

B.1. Existence of a management in $\mathrm{PC}^{2}$ in the $\mathrm{SMS}^{3}$ organizational chart

B.2. Existence of written $\mathrm{PMAF}^{5}$.

AFM

AFM

B.3. PC formally organized, with management in the organizational chart of SMS and written PMAF.
$\mathrm{AFM}^{4} \quad$ Indicate the level of PC organization in the city
Interview with the coordinator
Yes - $50 \%$ of cities

Interview with the coordinator

Yes $-61 \%$ of cities organization in the city Indicate the level of PC organization in the city
Interview with the coordinator

C. Medications selection

\section{C.1. Existence of REMUME $^{6}$}

C.2. Last updating of REMUME.

C.3. Percentage of medications of REM ${ }^{7}$ for the $\mathrm{APS}^{8}$ in the REMUME.

\section{Acquisition}

D.1. Percentage of municipal resources for medications acquisition spent in the modality Bidding.

D.2. Percentage of expense paid with medications respecting indebted expense

\section{E. Armazenamento}

E.1. Average percentage

of stock records

corresponding to

physical count.
AFM

\section{Evaluate if the city develops medication selection.}

AFM Evaluate the periodicity of REMUME updating

REMUME Evaluate the rationality of Number of items of REM

$$
\begin{aligned}
& \text { Interview with the } \\
& \text { coordinator }
\end{aligned}
$$

Interview with the coordinator

\section{REMUME}

in the REMUME / total of items of State Recording

$$
\text { Yes }-83 \% \text { of cities }
$$

$(* 100)$ Less than 3 years $-78 \%$ of
cities $95 \% \quad 70 \% \quad 100 \% \quad 10$

(1)

\begin{tabular}{ccccccc} 
AFM/SMS & $\begin{array}{c}\text { To know the destination } \\
\text { of resources for the } \\
\text { medications purchase in } \\
\text { the modality Bidding }\end{array}$ & $\begin{array}{c}\text { Expenses with medications } \\
\text { in bidding / total expenses } \\
\text { with medications for the } \\
\text { city. }(* 100) .\end{array}$ & $76 \%$ & $0 \%$ & $100 \%$ & 7 \\
SIOPS & $\begin{array}{c}\text { To evaluate the level } \\
\text { of financial execution } \\
\text { respecting to which was } \\
\text { planned for medications } \\
\text { acquisition }\end{array}$ & $\begin{array}{c}\text { Expenses paid for the } \\
\text { medications acquisition } /\end{array}$ & & & & \\
Indebted expenses $(* 100)$ & $84 \%$ & $33 \%$ & $100 \%$ & 18 \\
\hline
\end{tabular}


TABLE II - continuation

\begin{tabular}{|c|c|c|c|c|c|c|c|}
\hline \multirow[t]{2}{*}{ Evaluated indicator } & \multirow[t]{2}{*}{ Source } & \multirow[t]{2}{*}{ Objective } & \multirow[t]{2}{*}{ Construction strategy } & \multicolumn{4}{|c|}{ Results } \\
\hline & & & & Mean & Lower & Higher & $\mathrm{N}$ \\
\hline \multicolumn{8}{|c|}{ F. Programming/Distribution } \\
\hline $\begin{array}{l}\text { F.1. Average } \\
\text { immediate availability } \\
\text { of medications at } \\
\text { warehouse. }\end{array}$ & $\mathrm{AM}^{9}$ & $\begin{array}{l}\text { To evaluate the } \\
\text { availability of marker- } \\
\text { medications at warehouse }\end{array}$ & $\begin{array}{c}\text { For every marker- } \\
\text { medication, verify the } \\
\text { presence at warehouse. } \\
\text { Number of present items / } \\
\text { total of evaluated items } \\
\left({ }^{*} 100\right)\end{array}$ & $89 \%$ & $70 \%$ & $100 \%$ & 17 \\
\hline $\begin{array}{l}\text { F.2. Average immediate } \\
\text { availability of } \\
\text { medications at the }\end{array}$ & $\mathrm{US}^{10}$ & $\begin{array}{l}\text { To evaluate the } \\
\text { availability of marker- } \\
\text { medications at the Health }\end{array}$ & $\begin{array}{l}\text { For every marker- } \\
\text { medication, verify the } \\
\text { presence at the Health Unit. }\end{array}$ & & $64 \%$ & $91 \%$ & 33 \\
\hline dispensation place. & & Units & $\begin{array}{l}\text { Number of present items } \\
\text { / total of evaluated items } \\
\qquad(* 100) \text {. }\end{array}$ & $81 \%$ & $64 \%$ & $91 \%$ & 33 \\
\hline $\begin{array}{l}\text { F.3. Average percentage } \\
\text { of medications } \\
\text { available in the place } \\
\text { of dispensation and } \\
\text { appearing also at the } \\
\text { municipal warehouse } \\
\text { stock. }\end{array}$ & $\begin{array}{l}\text { US } \\
\text { AM }\end{array}$ & $\begin{array}{l}\text { To evaluate the } \\
\text { effectiveness of } \\
\text { distribution strategy } \\
\text { adopted in the city. }\end{array}$ & $\begin{array}{l}\text { Number of marker- } \\
\text { medications available in } \\
\text { the Health Unit / number } \\
\text { of marker-medications } \\
\text { available in the warehouse } \\
\qquad\left({ }^{*} 100\right)\end{array}$ & $92 \%$ & $50 \%$ & $115 \%$ & 33 \\
\hline
\end{tabular}

TABLE III - Availability of key drugs observed in the US, in the local distribution center, and in both, simultaneously. Regional Management of Health of Belo Horizonte, MG, 2005

\begin{tabular}{lccc}
\hline Medication & \multicolumn{3}{c}{ Availability } \\
\cline { 2 - 4 } & US & Warehouse & Both \\
\hline Acetylsalicylic acid $100 \mathrm{mg}$ tablet & $84.8 \%$ & $100.0 \%$ & $87.5 \%$ \\
Amoxicillin 500 mg caps. & $78.8 \%$ & $94.1 \%$ & $86.7 \%$ \\
Amoxicillin Powder 50 mg/ml susp. & $81.8 \%$ & $94.1 \%$ & $90.0 \%$ \\
Benzathine benzylpenicillin 1.200.000UI & $60.6 \%$ & $94.1 \%$ & $66.7 \%$ \\
Cimetidine 200 mg tablet & $66.7 \%$ & $76.5 \%$ & $91.7 \%$ \\
Diazepam 10 mg tablet & $60.6 \%$ & $100.0 \%$ & $62.5 \%$ \\
Erythromycin 250 mg tablet & $78.8 \%$ & $88.2 \%$ & $92.9 \%$ \\
Erythromycin 25 mg/ml susp. & $66.7 \%$ & $82.4 \%$ & $84.6 \%$ \\
Glibenclamide 5 mg tablet & $84.8 \%$ & $100.0 \%$ & $87.5 \%$ \\
Hydrochlorothiazide 50 mg tablet & $63.6 \%$ & $76.5 \%$ & $84.0 \%$ \\
Imipramine 25 mg coated tablet & $60.6 \%$ & $88.2 \%$ & $69.0 \%$ \\
Mebendazole 20 mg/ml susp. & $66.7 \%$ & $76.5 \%$ & $91.7 \%$ \\
Metronidazole 250 mg tablet & $84.8 \%$ & $94.1 \%$ & $93.3 \%$ \\
Paracetamol 500 mg tablet & $57.6 \%$ & $64.7 \%$ & $95.0 \%$ \\
Propranolol 40 mg tablet & $69.7 \%$ & $88.2 \%$ & $79.3 \%$ \\
Oral rehydration salts powder envelope & $81.8 \%$ & $94.1 \%$ & $90.0 \%$ \\
Salbutamol 0.4 mg/ml sol. Oral & $81.8 \%$ & $94.1 \%$ & $90.0 \%$ \\
Sulphamet. + Trimet. 400 + 80 mg, tablet & $87.9 \%$ & $100.0 \%$ & $90.6 \%$ \\
Sulphamet. + Trimethoprim 4\%+ 0.8 susp. & $78.8 \%$ & $88.2 \%$ & $92.9 \%$ \\
Ferrous sulphate 25mg Fe/ml oral sol. & $78.8 \%$ & $94.1 \%$ & $86.7 \%$ \\
\hline Mean availability & $\mathbf{7 4 \%}$ & $\mathbf{8 9 \%}$ & $\mathbf{8 3 \%}$ \\
\hline
\end{tabular}


budgets for drugs purchase. However, it is important to notice the existence of municipalities where no acquisition was done by bidding, or in which only $33 \%$ of resources were effectively spent with drug, with respect to indebted expenses.

Some components of PA chain have demonstrated weak performance. The inventory control in the local distribution center, for instance, was revealed inefficient, since in many cases the actual stock count did not match the inventory control. That could be explained by the fact that the distribution to the US took place in a moment earlier to the count process done, or even during such process, without the update in the inventory control. However, considering that the update in the stock control system should occur in the exact moment they are put in effect, these discordances do not attenuate the weak performance of evaluated system control. This inefficiency raises concerns, given the characteristic of PA organization, in which different components determine themselves mutually in a chain process (Perini, 2003), so the lack of inventory control could influence negatively the acquisition and programming process.

Regarding the drug availability in the health facilities, the low presence of imipramine and benzathine benzylpenicillin is justified by the fact that in many municipalities, drugs with central nervous system action or injectable drugs as well were only made available in some US. The low availability in the local distribution center of cimetidine $200 \mathrm{mg}$ and hydrochlorothiazide 50 mg (both with 77\%) could be explained by the fact that these drugs were recently replaced by other, in the State Essential Drug List.

The causes of non-supplying in the US, of drugs that were found in the distribution center, were not investigated; however, two situations observed during the data collection could explain this fact: the termination of the US stock before the next distribution, and the coincidence between the collection data moment and the drug arrival to municipal distribution center. Anyway, both situations characterize planning problems in the system supplying chain. Further investigation could evaluate the number of non-supplying days of a given drug in the US, and compare this value to the number of non-supplying days of the same drug in the distribution center.

The discussion about quality improvements in the basic healthcare drives, directly or indirectly, to the notion of evaluation. The evaluation area of programs, services, interventions and technologies in the health area passes through the outgrowth and diversification of concepts and methods, in order to enable the construction of a tool to support the implementation of public policies (Novaes, 2000). In the public sector, there is a higher interest on the development of evaluations programs with emphasis in quality or in cost-effectiveness. The consolidation of SUS requires more and more the application of evaluation methods and the utilization of indicators for this purpose allow the establishment of standards, as well as the following-up of their evolution along the years. The responsible sectors for PA organization should reinforce their actuation in this sense.

This work allowed the recognition of some essential aspects of organization and functioning of pharmaceutical assistance, within a GRS of Minas Gerais. The initiative should be considered as a starting point for the construction of more refined instruments, being respected the balance between the necessity of deeper evaluations and the simplicity of indicators relationship, instruments and collection process for their routine application, or application at determined periodicity, for system monitoring.

\section{CONCLUSIONS}

The procedures to evaluate pharmaceutical assistance adopted in this work showed to be feasible at the municipal level. The data have pointed out: (a) that US deprived of items that were available in the local distribution center, apparently, represents a fragility in the distribution strategies and stock control, demonstrating the need for mechanisms to manage them; (b) the advancements in the effectiveness of important steps for the evolution of the whole system, such as the elaboration and updating of Municipal Essential Drug List and the mechanisms of acquisition, suggest that the efforts for reorientation of pharmaceutical assistance, which include the pharmacists enabling and valorization, begin to produce positive results.

The impact of these results over the user healthcare and the efficiency of drugs expenses are now challenges to be faced, besides the establishment of a systematic monitoring process for routinely admeasurements of its functioning.

\section{ACKNOWLEDGEMENT}

The authors thank to: Itamar Soares Júnior, for his participation in the data collection, Maria de Fátima Fassy and Mirthes Machado from the State Secretariat of Health of Minas Gerais by the institutional feasibility of this work. 


\section{REFERENCES}

BARATA, L.B.; TANAKA, O.Y.; MENDES, J.D. Por um processo de descentralização que consolide os princípios do Sistema Único de Saúde. Rev. Saúde Pública v.13, n.1, p.15-24, 2004.

BRASIL. Ministério da saúde. Portaria Gabinete do Ministro n ${ }^{\circ}$ 3.916, 30 de outubro de 1998. Aprova a Política Nacional de Medicamentos. Diário Oficial da União, Brasília, 10 de janeiro de 1998. Seção 1, p.18.

BRASIL. Ministério da saúde. Portaria Gabinete do Ministro $\mathrm{n}^{\circ} 176,8$ de março de 1999. Estabelece o Incentivo à Assistência Farmacêutica Básica. Diário Oficial da União, Brasília, 20 de maio de 1999. Seção 1, p.22

COSEndey, M.E. Análise da implantação do Programa Farmácia Básica: Um estudo multicêntrico em cinco estados do Brasil. Rio de Janeiro, 2000. p.358. [Tese de Doutorado. Escola Nacional de Saúde Pública].

MANAGEMENT SCIENCES FOR HEALTH. Rapid pharmaceutical management assessment: an indicator-based approach. Arlington: MSH, 1995. p.191.

MARIN, N.; LUIZA, V.L.; CASTRO, C.S.; SANTOS, S.M. Assistência farmacêutica para gerentes municipais. Rio de Janeiro: OPAS/OMS, 2003. p.373.
NOVAES, H. Avaliação de programas, serviços e tecnologias em saúde. Rev. Saúde Pública, v.34, n.5, p.547-559, 2000.

PERINI, E. Assistência farmacêutica: fundamentos teóricos e conceituais. In: Medicamentos e assistência farmacêutica. Belo Horizonte: Coopmed Editora Médica, 2003. p.9-30.

SUPERINTENDÊNCIA de Ações de Saúde. Diretoria de assistência farmacêutica. Programa farmácia de Minas. Belo Horizonte: Secretaria de Estado de Saúde, 2003. p.25.

SUPERINTENDÊNCIA de Ações de Saúde. Diretoria de assistência farmacêutica. Programa farmácia de Minas: projeto de reorientação da assistência farmacêutica no estado de Minas Gerais. Belo Horizonte: Secretaria de Estado de Saúde, 2004. p.43.

WORLD HEALTH ORGANIZATION. Indicators for monitoring national drug policies: A Practical manual. Geneva: WHO, 1999. p.226.

WORLD HEALTH ORGANIZATION. How to investigate drug use in health facilities: select drug use indicators. Geneva: WHO, 2003. p.92.

Received for publication on $20^{\text {th }}$ february 2008 Accepted for publication on $17^{\text {th }}$ november 2008 